\title{
Budaya Religius Dalam Pembentukan Karakter Peserta Didik Di SMP Islam Ulul Albab Nganjuk
}

\author{
Misfaf Abdul Aziz, ${ }^{1}$ Ahmad Masrukin ${ }^{2}$ \\ ${ }^{1}$ Pascasarjana Institut Agama Islam Tribakti Kediri, ${ }^{2}$ Institut Agama Islam Tribakti Kediri \\ 1azis1005@gmail.com,2ahmadmasrukin4@gmail.com
}

\begin{abstract}
This paper is to examine the religious culture of the character formation of students in Ulul Albab Islamic Middle School Nganjuk. This study departs from two research questions. "How is the implementation of religious culture in the Ulul Albab Nganjuk Islamic Middle School?", "What is the impact of religious culture in the Ulul Albab Nganjuk Islamic Middle School?". With these two questions the researchers found that first, religious culture is a culture with positive activities that contain Islamic religious values that are very thick. While the religious culture of educational institutions is an effort to realize the values of religious teachings as a tradition in behavior and organizational culture that is followed by all citizens in educational institutions. The religious culture at Ulul Albab Islamic Middle School contains the implementation of tartil and tahfidz every morning, then continues with the Dhuha Praying in touch, at the time of Dzuhur students are required to pray in congregation, and the last is the implementation of a special mujahadah which is held once a month every 8th, in it contains Dhikr, prayers, and Sunnah Prayers. Second, the impact of the application of religious culture in Ulul Albab Nganjuk Islamic Middle School on the character of students includes the politeness of the students towards the teacher and those who are older than him, a sense of tolerance among friends, a reduction in the nature of bullying, so it is more disciplined with religious habituation, especially in religious habituation. matters of worship, and students become more responsible.
\end{abstract}

Keywords: Religious Culture, Student Character

\begin{abstract}
Abstrak
This paper is to examine the religious culture of the character formation of students in Ulul Albab Islamic Middle School Nganjuk. This study departs from two research questions. "How is the implementation of religious culture in the Ulul Albab Nganjuk Islamic Middle School?", "What is the impact of religious culture in the Ulul Albab Nganjuk Islamic Middle School?". With these two questions the researchers found that first, religious culture is a culture with positive activities that contain Islamic religious values that are very thick. While the religious culture of educational institutions is an effort to realize the values of religious teachings as a tradition in behavior and organizational culture that is followed by all citizens in educational
\end{abstract}


institutions. The religious culture at Ulul Albab Islamic Middle School contains the implementation of tartil and tahfidz every morning, then continues with the Dhuha Praying in touch, at the time of Dzuhur students are required to pray in congregation, and the last is the implementation of a special mujahadah which is held once a month every 8th, in it contains Dhikr, prayers, and Sunnah Prayers. Second, the impact of the application of religious culture in Ulul Albab Nganjuk Islamic Middle School on the character of students includes the politeness of the students towards the teacher and those who are older than him, a sense of tolerance among friends, a reduction in the nature of bullying, so it is more disciplined with religious habituation, especially in religious habituation. matters of worship, and students become more responsible.

Kata Kunci: Budaya Religius, Karakter Peserta Didik

\section{Pendahuluan}

Krisis moral yang melanda bangsa ini nampaknya menjadi sebuah kegelisahan bagi semua kalangan. Bagaimana tidak dari maraknya kasus korupsi yang tidak pernah surut bahkan mengalami peningkatan dari waktu ke waktu. Disisi lain krisis ini menjadi komplek dengan berbagai peristiwa yang cukup memilukan seperti tawuran pelajar, penyalahgunaan obat terlarang, pergaulan bebas, aborsi, penganiayaan yang disertai pembunuhan. Fenomena ini sesungguhnya sangat berseberangan dengan suasana keagamaan dan kepribadian bangsa Indonesia. Jika krisis ini dibiarkan begitu saja dan berlarutlarut apalagi dianggap sesuatu yang biasa maka segala kebejatan moralitas akan menjadi budaya. Sekecil apapun krisis moralitas secara tidak angung akan dapat merapuhkan nilai-nilai kehidupan berbangsa dan bernegara. ${ }^{1}$

Fenomena tersebut sebenarnya juga dipengaruhi oleh perkembangan sains dan teknologi yang sangat pesat. Seluruh manusia dan teknologi saling berlomba untuk mengikuti perkembangannya. Namun, hal itu harus dibarengi dengan sikap yang bijaksana untuk mempertahankan budaya tradisional. Seperti, gotong royong, giat beribadah, bertanggung jawab, dan sifat positif yang lainnya.

Istilah "anak zaman now" sudah tidak asing ditelinga masyarakat. Istilah itu diperuntukan untuk anak-anak yang terlahir di zaman yang sekarang yang teknologi dan lain-lain sudah berkembang. Tentu, mereka akan memanfaatkan hal ini. Karena orang tua, guru, teman, tetangga, saudara atau yang lainnya tidak akan menyia-nyiakan pemanfaatan perkembangan zaman. Tapi yang miris dalam kasus ini adalah, tentang istilah anak zaman now yang hanya memanfaatkan untuk kesenangan pribadi yang menimbulkan kebiasaan buruk. Seperti main game di ponsel tanpa memikirkan waktu belajar, melihat video

Pemikiran Keislaman, 29(1), 1-22. https://doi.org/10.33367/tribakti.v29i1.560 
di youtobe tanpa didampingi orang tua kemudian menirukan hal-hal yang ditayangkan disana yang mengakibatkan kekerasan, pelecehan dan lain-lain

Masyarakat baik; orang tua, pendidik dan pemimpin agama sekarang menghadapi masalah besar dalam pendidikan, yaitu tentang cara terbaik untuk mendidik kaum muda dan mempersiapkan mereka untuk menghadapi tantangan global di masa depan. ${ }^{2}$

Pendidikan formal di sekolah/ madrasah, bisa menjadi salah satu penyebabnya karena pendidikan di Indonesia lebih fokus pada pengembangan intelektual atau kognitif saja, sedangkan soft skill atau aspek nonakademik sebagai unsur utama pendidikan moral belum ditangani. ${ }^{3} \mathrm{Di}$ sekolah-sekolah Negeri maupun Swasta kini sudah digencarkan tentang pendidikan karakter, supaya pendidikan formal dan pendidikan karakter bisa seimbang.

Pendidikan karakter telah mendapat perhatian dari berbagai negara dalam rangka mempersiapkan generasi yang baik, tidak hanya untuk kepentingan warga negara individu, tetapi juga untuk warga negara secara keseluruhan. ${ }^{4}$ Tujuan dari pendidikan pribadi adalah untuk mengajarkan beberapa nilai tradisional, yang diterima secara luas sebagai dasar untuk perilaku yang baik dan bertanggung jawab. Nilainilai ini juga digambarkan sebagai perilaku moral. ${ }^{5}$

Dengan mengembangkan nilai pendidikan karakter di sekolah sebagai upaya dan upaya untuk meningkatkan moral bangsa, sekolah bertanggung jawab atas pengembangan serius kemampuan dan sikap siswa. Seiring dengan mempraktikkan kecerdasan, sekolah juga bertanggung jawab untuk mendidik sikap dan etika siswa. Yaitu, melalui tiga upaya pendidikan, termasuk pembiasaan, pembelajaran dan pemodelan, dengan penerapan ketiga hal ini, siswa diharapkan terbiasa dan antusias dalam berbuat baik. ${ }^{6}$

Salah satu pengembangan pribadi yang dapat dilakukan di sekolah adalah pengembangan budaya agama. Perkembangan budaya agama ini menjadi penting karena dengan mengidentifikasi siswa dan contoh mereka, mereka diharapkan dapat mempengaruhi perilaku mereka dalam perilaku. Fuad Hassan juga percaya bahwa pendidikan adalah budaya. ${ }^{7}$ Melalui pengembangan

tribakti.ac.id/index.php/tribakti/article/view/1 3; Muzhofar Akhwan, h. 62.

${ }^{5}$ Muzhofar Akhwan, h. 62.

6 Jauhar Fuad, "Strategi Pembelajaran Kooperatif (Studi Eksperimen)," Jurnal Pemikiran Keislaman 20, no. 1 (March 3, 2013), http:// ejournal.iai-

tribakti.ac.id/index.php/tribakti/article/view/9 4.

${ }^{7}$ Tony d. Widiastono (ed), Pendidikan Manusia Indonesia (Jakarta: Kompas, 2004) h. 52. 
kegiatan keagamaan, dapat dikatakan bahwa proses pendidikan terus berlanjut.

Sifat positif terlahir dari kebiasaan pembentukan karakter dari usia dini Karakter yang baik akan terbentuk jika orang tua, guru dan lingkungan sangat mendukung untuk membentuk karakter tersebut. Karena dari kebiasaan terbentuklah kepribadian.

Maka dengan ini peneliti ingin meneliti tentang budaya religius terhadap pembentukan karakter peserta didik di SMP Islam Ulul Albab Nganjuk. SMP Islam Ulul Albab Nganjuk merupakan SMP Islam di bawah naungan YPI Pondok Pesantren Daru Ulil Albab Nganjuk. Smp ini merupakan sekolah yang sejak berdirinya memiliki orientasi membangun institusi pendidikan terpadu dari berbagai komponen dan unit-unit pendidikan yang ada. Maka dari itu peneliti ingin meneliti Smp Islam Ulul Albab Nganjuk dikarenakan di sekolah ini menanamkan nilai-nilai religius seperti pembiasaan sholat dhuha setiap pagi hari setelah itu dilanjutkan dengan hafalan surah-surah pendek kemudian juga sholat fardhu berjamaah.

\section{Metode}

Berdasarkan jenis penelitian ini adalah penelitian kualitatif dengan pendekatan deskriptif. Penelitian kualitatif adalah kegiatan penelitian di mana peneliti tidak menggunakan angka dalam pengumpulan data dan dalam menafsirkan hasil. Namun, ini tidak

8 Suharsimi Arikunto, Prosedur Penelitian, (Jakarta: Rineka Cipta, 2002), hal. 10. berarti bahwa penelitian kualitatif tidak memungkinkan penggunaan angka sama sekali. ${ }^{8}$ Apa yang salah adalah pengumpulan dan interpretasi data yang disediakan oleh para peneliti menggunakan rumus statistik.

Penelitian deskriptif adalah pencarian fenomena atau kelompok tertentu yang peneliti peroleh dari topik dalam bentuk individu, organisasi, industri, atau perspektif lainnya. Tujuannya adalah untuk mengklarifikasi aspek yang relevan dari fenomena yang diamati, dan untuk menjelaskan karakteristik dari fenomena atau masalah yang ada. Secara umum, penelitian deskriptif ini tidak menggunakan hipotesis (selain hipotesis) sehingga penelitian tidak perlu merumuskan hipotesis. Dalam pencarian deskriptif, data yang dikumpulkan bukan angka, tetapi dalam bentuk kata atau gambar. Data yang dimaksud dapat berasal dari skrip wawancara, catatan lapangan, foto, video, dokumen pribadi, catatan atau catatan, dan dokumen resmi lainnya. ${ }^{9}$

Penelitian kualitatif tidak hanya untuk menemukan kebenaran, tetapi untuk memahami subjek dunia sekitarnya. Penelitian ini menggunakan pendekatan kualitatif karena penelitian ini menggambarkan fenomena yang diteliti dalam bentuk deskripsi yang menggambarkan bagaimana budaya agama, termasuk doa jamaah, shalat sunnah, pengajaran Alquran, menghafal pesan singkat, alienasi, mujahidin, dan

9 Lexy J. Moleong, Metode Penelitian Kualitatif, (Bandung: Remaja Rosda Karya, 2014),hlm.11. 
kegiatan budaya keagamaan dapat diterapkan untuk membentuk kepribadian siswa di di SMP Islam Ulul Albab Nganjuk.

\section{Hasil dan Pembahasan}

\section{Budaya religious}

Kamus besar budaya Indonesia didefinisikan sebagai: pikiran, adat istiadat, sesuatu yang berevolusi. Sesuatu biasanya menjadi sulit untuk diubah. ${ }^{10}$ Koentjaraningrat mengatakan bahwa elemen global budaya adalah 1) sistem keagamaan dan upacara keagamaan, 2) sistem dan organisasi masyarakat, 3) sistem pengetahuan, 4) bahasa, 5) seni, 6) sistem kehidupan, dan 7) sistem dan peralatan teknologi. Budaya memiliki setidaknya tiga bentuk, yaitu budaya sebagai 1) seperangkat gagasan, gagasan nilai, norma, norma, dll., 2) kompleks perilaku manusia dalam masyarakat, dan 3) sebagai hal-hal tindakan manusia. ${ }^{11}$ Pakar budaya dewasa ini percaya bahwa budaya bukan hanya hasil yang mulia dan indah dari aktivitas manusia seperti seni, sastra dan filsafat, tetapi setiap aktivitas manusia untuk mengantisipasi hidupnya. ${ }^{12}$

Jadi yang disebut budaya adalah seluruh gaya hidup manusia yang lahir dari ide dan kebiasaan yang menjadi ciri komunitas atau populasi yang bergerak bersama. Budaya adalah produk ciptaan manusia, tindakan dan inisiatif yang lahir atau direalisasikan setelah diterima oleh masyarakat atau masyarakat tertentu dan dilaksanakan dalam kehidupan seharihari dengan kesadaran penuh tanpa paksaan dan diteruskan ke generasi berikutnya bersama-sama.

Agama didasarkan pada pembangunan pengetahuan dalam tiga kerangka kerja ilmiah: filsafat dasar, tujuan, nilai-nilai, dan orientasi pendidikan. Pertama, dasar filsafat religiusitas pendidikan adalah filsafat teologis yang menjadikan Tuhan pijakan. Kedua, tujuan religiositas dalam pendidikan adalah untuk membangun kehidupan duniawi melalui pendidikan sebagai bentuk pengabdian terhadapnya. Ini dapat dijelaskan oleh fakta bahwa kehidupan duniawi bukanlah tujuan akhir, tetapi sekarang hanyalah sarana transmisi menuju kehidupan abadi dan abadi sebagai tujuan terakhir kehidupan manusia. Ketiga, nilai dan orientasi religiusitas pendidikan menjadikan iman dan kesalehan jiwa dalam setiap proses pendidikan yang dilakukan.

Berdasarkan tiga kerangka kerja konsep religiusitas pendidikan di atas, dapat dijelaskan bahwa religiositas pendidikan meningkatkan kecerdasan spiritual siswa dalam pendidikan dan kehidupan. Mengutuk pendidikan melalui kecerdasan spiritual juga memberikan panduan bagi guru untuk mengajarkan pentingnya religiusitas kepada siswa. Mengutuk pendidikan mempertajam kualitas kecerdasan spiri-

12 Sudiarja, Agama di Zaman yang Berubah, (Yogyakarta: Kanisius, 2010), 29. 
tual terhadap guru dan siswa. Hal ini dilakukan dengan memahami nilai-nilai kejujuran, integritas, kebajikan, solidaritas dan solidaritas sosial bagi siswa sejak usia dini, sehingga guru dapat memperoleh ini melalui sikap ideal dalam setiap proses yang terjadi dalam pendidikan, semua hal ini tentu saja tidak Ini bias terlepas dari peran dan perkembangan pendidikan Islam, termasuk realisasi budaya agama sekolah. ${ }^{13}$

Sikap keagamaan harus ditanamkan di lembaga pendidikan untuk membentuk budaya agama yang kuat di lembaga pendidikan ini. Selain itu, penanaman nilai-nilai agama penting untuk menstabilkan etos kerja dan etika ilmiah dari seluruh komunitas akademik di lembaga pendidikan. Selain itu, itu juga harus dimasukkan dalam perguruan tinggi yang melakukan kegiatan pendidikan bagi siswa tidak hanya untuk mendapatkan uang, tetapi bagian dari ibadah.

Religiusitas seseorang memanifestasikan dirinya dalam berbagai aspek kehidupannya. Aktivitas yang beragam terjadi tidak hanya ketika seseorang melakukan perilaku ritual (ibadah), tetapi juga ketika melakukan aktivitas lain yang didorong oleh kekuatan gaib. Ini bukan hanya tentang aktivitas visual yang dapat dilihat dengan mata, tetapi juga aktivitas tak terlihat yang terjadi di hati. ${ }^{14}$

13 Asmaun Sahlan, mewujudkan Budaya Religius di Sekolah, (Malang, UIN Maliki Press, 2010), 32-33.
Agama bukan sekadar ritual seperti berdoa, membaca doa. Agama lebih dari itu, perilaku umum orang yang pantas dipuji, yang dilakukan agar mendapat kesenangan atau kepuasan dari Tuhan. Karena itu, agama mencakup semua perilaku manusia dalam kehidupan ini, yang perilakunya merupakan keselamatan manusia yang saleh berdasarkan kepercayaan atau kepercayaan pada Tuhan dan tanggung jawab pribadi di masa mendatang. ${ }^{15}$

Dari beberapa penjelasan di atas, dapat dipahami bahwa nilai-nilai agama adalah nilai-nilai kehidupan yang mencerminkan pertumbuhan dan perkembangan kehidupan beragama yang terdiri dari tiga elemen utama: kepercayaan, ibadah dan moralitas yang membimbing perilaku sesuai dengan aturan ilahi untuk mencapai kemakmuran dan kebahagiaan dalam kehidupan di dunia dan akhirat.

Bentuk budaya religius dapat mencakup budaya senyum, salam, rasa hormat dan toleransi, puasa Senin, doa Duha, siang Holt di jemaah, mempelajari Alquran, doa budaya, dan berdoa bersama. 16 Koentjaraningrat juga mengutip Ismail Sahlan mengkategorikan aspek-aspek budaya berdasarkan dimensi bentuknya, yaitu: (1) kelompok atau gagasan yang kompleks seperti gagasan, pengetahuan, nilai, kepercayaan, norma dan sikap. (2) Kelompok

15 Nurcholis Madjid, Masyarakat Religius, (Jakarta: Paramadina, 1997), 124.

16 Asmaun sahlan, Mewujudkan Budaya Religius di Sekolah , 116 
aktivis seperti pola komunikasi tradisional, tarian dan perayaan. (3) Bahan yang dihasilkan dari hal-hal seperti seni, peralatan, dan sebagainya. Pada saat yang sama, menurut Robert $\mathrm{K}$. Marton adalah di antara semua elemen budaya, dalam arti bahwa ada nilai budaya yang mewakili ide abstrak yang hidup dalam pikiran. ${ }^{17}$

Dalam hal ini, budaya keagamaan sekolah adalah cara berpikir dan metode kerja bagi warga sekolah berdasarkan nilai-nilai agama. Agama menurut Islam adalah implementasi dari ajaran agama secara keseluruhan. ${ }^{18}$ Bentuk budaya agama adalah upaya untuk mengembangkan PAI di sekolah sebagai berikut: (1) tambahan jam belajar dan keluarga mata pelajaran PAI. (2) meningkatkan kualitas pembelajaran, (3) pengembangan melalui kegiatan ekstrakurikuler, dan (4) pengembangan melalui pendokumentasian nilai-nilai agama. ${ }^{19}$

\section{Karakter Peserta Didik}

Kepribadian adalah kualitas mental, kekuatan moral, nama atau reputasi. Karakter adalah properti yang dimiliki oleh objek atau individu. Karakteristik ini asli dan radikal dalam kepribadian individu dan merupakan kekuatan pendorong untuk bagaimana orang tersebut berperilaku dan berperilaku dan berbicara serta menanggapinya. ${ }^{20}$
Elemen terpenting dalam pembentukan kepribadian adalah pikiran karena pikiran di mana ada semua program yang terbentuk dari pengalaman hidupnya. ${ }^{21}$ Program ini kemudian membentuk sistem kepercayaan yang pada akhirnya dapat membentuk pola berpikir yang dapat memengaruhi perilaku. Jika program yang dimasukkan kompatibel dengan prinsip kebenaran universal, perilakunya bertentangan dengan hukum kodrat. Tujuan dari mengajar karakter adalah untuk membuat seseorang menjadi cerdas dan cerdas, dalam arti bahwa itu dapat mengubah orang menjadi lebih baik dalam pengetahuan, sikap dan keterampilan. ${ }^{22}$

Istilah "pendidikan pribadi" telah muncul dalam gerakan besar-besaran di seluruh dunia sebagai bentuk kepedulian untuk mempersiapkan siswa yang berkarakter baik. Semua lembaga pendidikan dasar dan menengah menyebarkan pendidikan karakter, termasuk Indonesia mulai tahun 2010. Dunia Muslim menggunakan istilah "pendidikan moral" yang terus berlanjut sepanjang sejarah peradaban Islam dan berhasil membentuk karakter Islam. Karakteristik pendidikan moral terutama dalam pembersihan spiritual dan kepatuhan pada Tuhan. Penelitian dari berbagai negara Muslim menunjukkan bahwa model etika pendidikan tidak

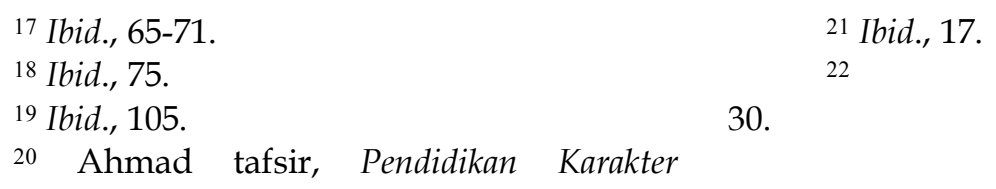


banyak berubah. Konservasi dari generasi ke generasi jauh tertinggal dari pengembangan pendidikan kepribadian. Siswa Muslim tidak cukup siap untuk memasuki kehidupan komunitas global. Seperti penggunaan sains dan teknologi Barat oleh semua orang (termasuk Muslim), koordinasi pendidikan karakter harus diadaptasi sebagai alat dalam pendidikan moral, sehingga siswa tidak dibatasi dari perspektif lokal yang sempit dan dapat memasuki kehidupan komunitas global.

Adaptasi meliputi 1) konten pendidikan pribadi untuk komunitas global, 2) wawasan guru dan peran lembaga pendidikan, 3) beragam model pendidikan, 4) keterlibatan orang tua dan masyarakat, dan 5) asimilasi siswa lintas agama.

Untuk menerapkan pendidikan karakter di sekolah, ada tiga elemen penting yang perlu dipertimbangkan: prinsip, proses dan praktik. Ketika menerapkan prinsip ini, nilai-nilai yang diajarkan harus tercermin dalam kurikulum sehingga semua siswa di sekolah memahami nilai-nilai ini dengan benar dan dapat menerjemahkannya ke dalam perilaku nyata. Ini membutuhkan pendekatan yang harus diterapkan pada semua komponen sekolah (pendekatan sekolah), yaitu:

1) Sekolah / sekolah harus dilihat sebagai lingkungan seperti pulau dengan bahasa dan budaya mereka. Namun, sekolah juga harus memperluas pendidikan karakter tidak hanya untuk guru, staf dan siswa, tetapi juga untuk keluarga dan masyarakat.

2) Dalam mengelola kurikulum kepribadian, harus: Mengajarkan nilainilai yang terkait dengan sistem sekolah secara keseluruhan, diajarkan sebagai subjek yang tidak berdiri sendiri (subjek yang berdiri sendiri) tetapi diintegrasikan ke sekolah / sekolah yang mengakui dan mendukung subjek nilai-nilai yang diajarkan. ${ }^{23}$

3) Penekanan ditempatkan pada memotivasi bagaimana siswa menerjemahkan prinsip-prinsip nilai ke dalam perilaku pro-komunitas. Anak-anak yang kita anggap pribadi adalah anak-anak yang memiliki kecerdasan yang diabaikan dan tidak dihargai oleh budaya kita, karena kebanyakan anak sangat cerdas tetapi sebagian besar sekolah mengabaikannya. ${ }^{24}$

Karakter yang kohesif terletak pada hasil pemikiran, perasaan dan niat, serta olahraga yang mengandung nilainilai, kemampuan, kemampuan moral dan keras kepala dalam menghadapi kesulitan dan tantangan. Karakter individu ditafsirkan secara psikologis sebagai hasil dari integrasi empat bagian, yaitu hati, pikiran, perasaan, dan olahraga sehingga karakter utama individu dihasilkan: kejujuran, tanggung jawab, cerdas, bersih, sehat, peduli dan kreatif.. 
Budaya Religius Terhadap Pembentukan Karakter Peserta Didik di SMP Islam

\section{Ulul Albab Nganjuk}

Sebagai sekolah Islam dan dalam konteks pembentukan karakter dan karakter yang baik, Sekolah Menengah Islam Pertama Ulul Albab Nganjuk memiliki berbagai program sekolah agama. Program kegiatan dilaksanakan dalam bentuk pembiasaan sehari-hari, melalui pembelajaran PAI dan beberapa kegiatan ekstrakurikuler wajib, sebagaimana yang di temukan oleh peneliti yaitu tartil dan tahfidz setiap pagi hari, sehabis itu siswa melaksanakan Sholat Duha berjamaah, sehabis Sholat Duha di teruskan dengan pembacaan Surat- surat pilihan seperti surat Yasin, Al Mulk, Al Waqi' ah, Al Kahfi, dan Ar Rohman, yang selanjutnya ketika sudah menginjak waktu Dzuhur siswa melaksanaan Sholat Dzuhur Berjamaah, dan yang terakhir ialah pelaksanaan Mujahadah yang di laksanakan sebulan sekali setiap tanggal 8.

Hal positif tentu melahirkan hasil yang positif juga. Disini para siswa jikaselalu istiqomah dan bertahan dengan peraturan yang asing menurut mereka, maka hasil positif akan mereka dapatkan.

Walaupun awalnya mereka kesulitan mengerjakan hal baru, karena ada banyak teman seperjuangan, pekerjaan sulit pun jadi ringan. Disini banyak pemaparan dari siswa yang megakui jika kebiasaan mereka perlahan berubah sedikit demi sedikit mengarah ke yang lebih baik.

Dari berbagai data yang di peroleh, peneliti menemukan dampak dari penerapan budaya religius di SMP Islam Ulul Albab Nganjuk, di antaranya yaitu: kesopanan murid terhadap Guru serta kepada orang yang lebih tua darinya, ketenggangan rasa antar teman, berkurangnya sifat bullying, murid jadi lebih disiplin dengan adanya kebiasaankebiasaan yang bersifat religius terutama disiplin dalam hal ibadah, serta siswa jadi lebih bertanggung jawab, penemuan tersebut di peroleh peneliti melalui pengumpulan data lewat wawancara murid dan Guru, observasi, serta dokumentasi.

\section{Penutup}

Budaya religius merupakan budaya dengan kegiatan positif yang mengandung nilai-nilai agama Islam yang sangat kental. Sedangkan budaya pendidikan dari institusi pendidikan adalah upaya untuk mengakui nilai-nilai ajaran agama sebagai tradisi perilaku dan budaya organisasi yang diikuti oleh semua warga dari institusi pendidikan. Dengan menjadikan agama suatu tradisi di lembaga pendidikan, secara sadar atau tidak, ketika warga lembaga mengikuti tradisi yang melekat, warga negara yang sebenarnya dari lembaga pendidikan mempraktikkan ajaran agama.

Pelaksanaan budaya religious di SMP Islam Ulul Albab Nganjuk di terapkan pertama dengan pembiasaan tartil dan tahfidz yang di dalamnya mepelajari tata cara baca Al Qur'an meliputi tajwid, makhorijul huruf dan hal-hal yang berkaitan dengan bacaan $\mathrm{Al}$ Qur'an serta menghafal Al Qur'an, kedua pelaksanaan Sholat Dhuha berjamaah 
serta pembacaan surat-surat pilihan seperti surat Ar-Rahman, Al Mulk, AL Waqi'ah, Al-Kahfi serta Yasin, ketiga pelaksanaan Sholat Dhuhur bejamaah, keempat pelaksanaan Khusussiyah Mujahadah yang di laksanakan setiap tanggal 8 yang di dalamnya meliputi Sholat Dhuha, Sholat Hajat, Sholat Tasbih, Sholat Taubat, serta Dzikir-dzikir

Dampak dari penerapan budaya religious di SMP Islam Ulul Albab Nganjuk terhadap karakter peserta didik meliputi kesopanan murid terhadap guru dan orang yang lebih tua darinya, ketenggangan rasa antar teman, Berkurangnya sifat bullying, jadi lebih disiplin dengan adanya pembiasaanpembiasaan religius terutama dalam hal ibadah, serta siswa jadi lebih bertanggung jawab.

\section{Daftar Pustaka}

Akhwan, Muzhofar." Pendidikan Karakter: Konsep dan Implementasinya dalam Pembelajaran di Sekolah/Madrasah", El-Tarbawi, (2014), vol. 7: 64

Arikunto, Suharsimi. 2010. Prosedur Penelitian Suatu Pendekatan Praktik. Jakarta: Rineka Cipta.

Departemen Pendidikan dan Kebudayaan, Kamus Besar Bahasa Indonesia.online.

Djamaluddin, Ancok. 1995. Psikologi Islami, Solusi Islam atas Problem Psikologi. Cet.II, Yogyakarta: Pustaka Pelajar.

Fuad, Jauhar, "Pendidikan Karakter

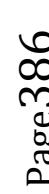

\section{Dalam Pesantren Tasawuf," Jurnal}

Pemikiran KeIslaman 23, no. 1

(February 28, 2013), http:/ / ejournal.iaitribakti.ac.id/index.php/tribakti/ar ticle/view/13; \

Hernowo. 2009. Sekolahnya Manusia. Bandung: Kaifa.

Ketut, Jelantik. 2015. Menjadi Kepala Sekolah Profesional, Yogyakarta: Depublish.

Madjid, Nurcholis. 1997. Masyarakat Religius, Jakarta: Paramadina.

Moleong, Lexy J. 2014. Metode Penelitian Kualitatif. Bandung: Remaja Rosda Karya.

Sahlan , Asmaun. 2010. Mewujudkan Budaya Religius di Sekolah. Malang, UIN Maliki Press.

Tafsir, Ahmad. 2011. Pendidikan Karakter Perspektif Islam. Bandung, PT. Remaja Rosdakarya.

Wasito, W., \& Turmudi, M. (2018). Penerapan Budaya Religius di SD al Mahrusiyah. Jurnal Pemikiran Keislaman, 29(1), 1-22. https://doi.org/10.33367/tribakti.v 29 i1.560

Zainudin, M. 2011. Paradigma Pendidikan Islam Holistik. Mataram: Ulumuna. 